Original Article

\title{
Evaluation of patient satisfaction in a Government Homeopathic Hospital in West Bengal, India
}

\author{
Munmun Koley ${ }^{1}$, Subhranil Saha ${ }^{1}$, Shubhamoy Ghosh ${ }^{2}$, \\ Rajarshi Mukherjee², Bapi Kundu², Ramkumar Mondal2, Rajib Purkait², \\ Jogendra Singh Arya ${ }^{1}$, Gurudev Choubey ${ }^{1}$
}

\author{
${ }^{1}$ Clinical Research Unit (Homeopathy), Siliguri, under CCRH, Govt. of India \\ 2 Mahesh Bhattacharyya Homeopathic Medical College \& Hospital, Govt. of West Bengal
}

\begin{abstract}
Discovering the degree of patient satisfaction in a homeopathic hospital setting may put substantial impact in improving health status and quality of care provided. In this study, the researchers evaluated the degree of patient satisfaction following medical encounters and reexamined the validity and reliability of the used questionnaires. An institutional, cross-sectional, observational study was carried out involving 390 participants in February, 2013 in five outpatient clinics of Mahesh Bhattacharyya Homeopathic Medical College and Hospital, Govt. of West Bengal, Howrah, India. A 12-item Japanese short-form self-administered consultation satisfaction questionnaire translated into Bengali with a 5-point Likert scale was used. The questionnaire generated 5 subscales - overall satisfaction, complete examination, whole person care, examination time, and patient centeredness. Visual analogue scales (VASs) of $100 \mathrm{~mm}$ were provided with each single question item and each subscale. The questionnaire appeared reliable and valid. Internal consistency scores Cronbach's a were between 0.7-0.9 and test-retest reliability Cohen's kappa was greater than 0.7 for each item. Concurrent validity Pearson's $r$ between total questionnaire and VASs was $0.60, \mathrm{p}<0.001$; each subscale scores $0.8<r<0.9, \mathrm{P}<$ 0.0001 , and each question score $0.8<r<0.9, \mathrm{p}<0.0001$. Comparison of mean scores of five different subscales for five different outpatient clinics yielded $F$ ratios between 4.3-9.8 ( $p<0.05$, df $=4,95 \%$ CI) establishing discriminant validity. Overall, the patients' satisfaction appeared to be high. Further works should be undertaken adapting the questionnaire globally in different languages.
\end{abstract}

Keywords: consultation, homeopathy, patient satisfaction, questionnaires.

\section{Introduction}

Higher degree of patient satisfaction has always been associated with improved health status [1-3] and has worked as an important predictor of health outcomes [4], compliance with treatment [4], doctor-patient relationship [5], and community involvement [5]. It also predicts whether patients re-attend for treatment [4]. This may also have implications for the effectiveness of both therapeutic and preventive interventions [6, 7]. So, discovering the degree of patient satisfaction in a medical practice setting may put substantial impact in increasing the quality of care provided [4]. Understanding what determines patient satisfaction with the consultation may have practical implications for improving patients' health outcomes, the quality assessment of novel service provision and the doctor-patient interaction, and thus implications for clinical governance, training and re-validation [4]. 
Patient satisfaction in a hospital set up usually depends on organizational aspects, doctor-patient relationship, communication style, and continuity of care [5]. Measuring subjective satisfaction using valid, reliable and sensitive questionnaire [8] is a challenging job due to inadequacy of multi-item scales developed for the purpose in India. So a Japanese derived multi-item short-form questionnaire [8] was translated into local vernacular Bengali and was used as an instrument to measure patient satisfaction in medical encounters in the state of West Bengal in India. The Consultation Satisfaction Questionnaire [5] and Medical Interview Satisfaction Scales (MISS-26; MISS-29; MISS-21) [4, 9, 10] were not chosen because of their lengths which were supposed to decrease the response rate [4].

One of the most noticeable changes in health care over the last few decades has been the increased involvement of patients in their treatment decisions [9]. Though identified the requirement of patient satisfaction surveys since last three decades in mainstream medicine [10], original research in homeopathy on this topic is seriously lacking; in fact, no published articles could be identified in spite of extensive literature search in different databases, namely Cochrane, MEDLINE, EMBASE, CINAHL, LILACS, SIGLE, CAM, CAMPAIN, HomInform, AMED, and CISCOM. In this study, the researchers intended to evaluate the degree of patient satisfaction following medical encounters as well as to re-examine the validity and reliability of the used questionnaires.

\section{Materials and methods}

Adopted study design was institutional, cross-sectional, observational study carried out in the month of February, 2013 in the out-patient clinics of Mahesh Bhattacharyya Homeopathic Medical College and Hospital, Govt. of West Bengal, Howrah, India.The study was of 3 weeks duration since its inception. Target participant size was390.Participants included were aged above 18 years and new patients visiting the outpatient facility of male and female medicine, obstetrics/gynecology, surgery, and pediatrics for the first time and giving written informed consent for filling the patient satisfaction questionnaire following consultations with their doctors. Patients who were too sick to complete the questionnaire, unable to read it, unwilling to stay after doctor visit, and not giving consent to join the study were excluded from the study. In the OPD of pediatrics, the guardians accompanying the patients were invited to take part in the study.

To avoid the tendency for respondents to rate everything at the top end of the scale, negative and positive statements were intermingled. Statements covering similar points were included in an attempt to ensure reliability. The directions to fill up the questionnaires were explained to all the participants in detail by the research assistants. Institutional ethics committee approved this study.

The questionnaire consisted of a previously validated set of 12 self-administered questions [8]. To facilitate understanding, the questions were translated by the authors into local vernacular Bengali. There was a balanced five-point Likert scale used for the responses to the question items, labelled as 'strongly agree', 'agree', uncertain', 'disagree', and 'strongly disagree'. For analytical purposes, zero, one, two, three and four were assigned respectively to these responses if the questions were positively worded, and the reverse order if negatively worded.

This scaling method was easy to complete and was tested in many surveys. It generated five subscales/dimensions - overall satisfaction (Q1, Q2), complete examination (Q3, Q4), whole person care (Q5, Q6), examination time (Q7, Q8, Q9), and patient centeredness (Q10, Q11, Q12). Thus maximum attainable scores for each subscale were8, 8, 8, 12, and 12 respectively, a total of 48 [8]. Visual analogue scales (VASs) of $100 \mathrm{~mm}$ were provided with each single question item and each subscale. (Table 1) 
Table 1: Items of the questionnaire

\begin{tabular}{|l|l|}
\hline $\begin{array}{l}\text { Questionnaire } \\
\text { subscales }\end{array}$ & Items \\
\hline Overall satisfaction & $\begin{array}{l}\text { Q1: I am very satisfied with the medical consultation that I had today. } \\
\text { Q2: The medical consultation that I had today has better point(s) than those of } \\
\text { other doctors. }\end{array}$ \\
\hline Complete examination & $\begin{array}{l}\text { Q3: This doctor examined me carefully and completely. } \\
\text { Q4: This doctor examined me perfectly. }\end{array}$ \\
$\begin{array}{l}\text { Q5: This doctor knows almost everything about me. } \\
\text { Q6: I think that this doctor really knows how I think. }\end{array}$ & $\begin{array}{l}\text { Q7: The time for the medical consultation with me was not long enough to deal } \\
\text { with everything I wanted.* } \\
\text { Q8: I wonder if this doctor could have spent a little longer time with me.* } \\
\text { Q9: the time for the medical consultation with me was a little bit too short.* }\end{array}$ \\
\hline Patient centeredness & $\begin{array}{l}\text { Q10: This doctor listened to my ideas. } \\
\text { Q11: This doctor listened to what I want him/her to do. } \\
\text { Q12: I think that this doctor is very honest. }\end{array}$ \\
\hline
\end{tabular}

*These items were negatively worded, and each of them was scored in the reverse order.

45 participants were requested to fill up the questionnaire again after an hour of the first round. This helped in testing the test-retest reliability of the measuring instrument. Cohen's kappa (к) statistics was used to provide an exact agreement between two sets of scores. It also controlled for chance agreement between ratings. Kappa values greater than 0.75 indicate strong agreement beyond chance; and those between 0.40 and 0.74 reflect fair to good agreement.

Instructions on the questionnaire promised anonymity and confidentiality; patients were asked to complete questionnaires, to place those in opaque envelopes, to seal and hand over to the research assistants (RM, BK, $\mathrm{RM}$, and RP) before leaving the hospital premises. Data were extracted manually by two researchers (MK, and SS) in data extraction sheets developed by the research team. Individual responses to the 12 questionnaires by each respondents $(n=390)$ were recorded in the extraction sheets, higher scores indicating greater satisfaction.

The dimensions/subscales identified in the analysis were also tested for internal reliability (Cronbach's alpha coefficient) and replicability (Pearson's $r$ product-moment correlation coefficient). Levels of reliability were compared with those obtained in the original study. To establish discriminant validity, patients' mean satisfaction scores for consultations in different out-patient clinics were compared. One-way analysis of variance (ANOVA) was computed on various dimensions as a method of multiple pair wise comparison amongst participants from five different OPDs. 
Different online calculators were used for statistical computations; e.g. 'NumberEmpire' [13] for skewness, 'EndMemo' [14] for kurtosis, 'UsableStats' [15] and 'Jumk.de' [16] for mean, standard deviation, median, and inter-quartile range, 'Wessa.Net' [17, 18] for Cronbach's alpha and Pearson's $r$, 'DfreeLon.org' [19] for kappa score, and 'DanielSoper' [20] for one way ANOVA.

\section{Results}

Socio-demographic data - Mean age of the participants in this survey was 37.63 years (SD = 10.95). Gender ratio was male : female $=142: 248$. Bengali was the first language in most of the patients $(\mathrm{n}=378,96.92 \%)$. Education level was $8^{\text {th }}$ standard or below: $\mathrm{n}=136,34.87 \% ; 9^{\text {th }}-10^{\text {th }}$ standard: $\mathrm{n}=82,21.02 \% ; 11^{\text {th }}-12^{\text {th }}$ standard: $\mathrm{n}=90 ; 23.08 \%$; graduate or above: $\mathrm{n}=82 ; 21.03 \%$. Habitat was mostly urban: $\mathrm{n}=273,70 \%$; and rural: $\mathrm{n}=117,30 \%$. Maximum patients were married: $\mathrm{n}=252 ; 64.62 \%$; unmarried: $\mathrm{n}=138 ; 35.38 \%$.

Research assistants helped the participants in filling up the questionnaire and thus response rate was $100 \%$. No missing data was found.

Table 2: Descriptive statistics for each question to indicate the variability in responses $(n=390)$

\begin{tabular}{|l|c|c|c|c|c|}
\hline Question items & Mean $\pm \mathrm{SD}$ & Median/IQR & Observed range & Skewness & Kurtosis \\
\hline Overall satisfaction & $3.66 \pm 0.54$ & $4 / 3-4$ & $2-4$ & -1.256744 & 3.5514 \\
\hline Q1 & $3.6 \pm 0.57$ & $4 / 3-4$ & $1-4$ & -1.392116 & 5.6461 \\
Q2 & $3.51 \pm 0.70$ & $4 / 3-4$ & $1-4$ & -1.610400 & 5.7927 \\
\hline Total & $7.11 \pm 1.17$ & $8 / 6-8$ & $\ldots$ & -1.363912 & 5.2459 \\
\hline Complete examination & $3.6 \pm 0.64$ & $4 / 3-4$ & $1-4$ & -1.802498 & 6.8112 \\
\hline Q3 & $3.67 \pm 0.55$ & $4 / 3-4$ & $2-4$ & -1.42823 & 4.0394 \\
Q4 & $3.5 \pm 0.82$ & $4 / 3-4$ & $0-4$ & -2.024001 & 7.2171 \\
\hline Total & $7.17 \pm 1.21$ & $8 / 6-8$ & $\ldots$ & -1.381602 & 4.1807 \\
\hline Whole person care & $3.53 \pm 0.63$ & $4 / 3-4$ & $1-4$ & -1.22592 & 4.4864 \\
\hline Q5 & $3.49 \pm 0.73$ & $4 / 3-4$ & $1-4$ & -1.209639 & 3.4676 \\
Q6 & $3.37 \pm 0.75$ & $4 / 3-4$ & $1-4$ & -0.862037 & 2.7887 \\
\hline Total & $6.86 \pm 1.38$ & $7.5 / 6-8$ & $\ldots$ & -1.007364 & 3.0532 \\
\hline Examination time & $3.42 \pm 0.83$ & $4 / 3-4$ & $0-4$ & -1.867342 & 7.2844 \\
\hline Q7 & $3.38 \pm 0.96$ & $4 / 3-4$ & $0-4$ & -1.916033 & 6.4212 \\
Q8 & $3.06 \pm 1.20$ & $3 / 3-4$ & $0-4$ & -1.300457 & 3.5825 \\
Q9 & $3.3 \pm 0.96$ & $4 / 3-4$ & $0-4$ & -1.596618 & 5.169 \\
\hline Total & $9.74 \pm 2.67$ & $10 / 9-12$ & $\ldots$ & -1.562264 & 5.369 \\
\hline Patient centeredness & $3.51 \pm 0.63$ & $4 / 3-4$ & $2-4$ & -0.900340 & 2.7419 \\
\hline Q10 & $3.58 \pm 0.71$ & $4 / 3-4$ & $0-4$ & -2.38228 & 10.3272 \\
Q11 & $3.54 \pm 0.72$ & $4 / 3-4$ & $1-4$ & -1.547784 & 4.8927 \\
Q12 & $3.64 \pm 0.59$ & $4 / 3-4$ & $1-4$ & -1.711097 & 6.1253 \\
\hline Total & $10.76 \pm 1.74$ & $12 / 9-12$ & $\ldots$ & -1.506708 & 5.0964 \\
\hline
\end{tabular}

SD: Standard Deviation; IQR: Inter-Quartile Range 
Table 2 shows the descriptive statistics of mean, standard deviation, median, inter-quartile range, skewness and kurtosis. All of the questions and dimensions were negatively skewed, indicating distributions with more positive ratings of the questionnaires and high level of patient satisfaction. Variable range of scores was observed for the questions or dimensions.

Reliability - Cronbach's alpha measure of internal consistency were computed for each of the five dimensions - overall satisfaction, complete examination, whole person care, examination time, and patient centeredness. All the dimensions yielded good to excellent reliability. The results are presented in table 3 with levels of acceptability. These results suggest that the subscales/dimensions of the questionnaire were internally consistent under the conditions of this study, as they satisfied the minimum criteria of 0.7 for internal consistency.

Table 3: Internal consistency evaluated by the value of Cronbach's alpha $(\mathrm{n}=390)$

\begin{tabular}{|c|c|c|}
\hline Subscales & Cronbach's alpha & Acceptability \\
\hline Total score (12 items) & 0.7791 & Good \\
\hline Overall satisfaction (2 items) & 0.9046 & Excellent \\
\hline Complete examination (2 items) & 0.8758 & Excellent \\
\hline Whole person care (2 items) & 0.9113 & Excellent \\
\hline Examination time (3 items) & 0.848 & Good \\
\hline Patient centeredness (3 items) & 0.8507 & Excellent \\
\hline
\end{tabular}

Concurrent validity - Pearson's $r$ product-moment correlation coefficient was used to compare responses between each question score and VAS score as well as each domain score and VAS score. Correlation was found to be extremely significant in total score $(r=0.60306, \mathrm{P}<0.001)$, domain scores $(0.8<r<0.9, \mathrm{P}<$ $0.0001)$, and each question score $(0.8<r<0.9, \mathrm{P}<0.0001)$. This association indicates satisfactory concurrent validity of the questionnaire and that all the dimensions and questionnaires were the same when measured for different OPD consultations. (Table 4)

Discriminant validity - In order to establish how well the consultation satisfaction questionnaires discriminated between different OPDs, mean scores and 95\% confidence intervals were computed for the five dimensions for five different OPDs. The results of this analysis are presented in table 5. Analysis of variance of mean scores on five different domains yielded $F$ ratios at $\mathrm{df}=4$ of $4.345(\mathrm{P}=0.002), 9.821(\mathrm{P}<0.000), 9.332$ $(\mathrm{P}<0.000), 5.385(\mathrm{P}<0.000)$, and $9.791(\mathrm{P}<0.000)$. ANOVA of mean VAS measures on the same five domains produced $F$ ratios at $\mathrm{df}=4$ of $1.074(\mathrm{P}=0.369), 6.262(\mathrm{P}<0.000), 10.295(\mathrm{P}<0.000), 3.952(\mathrm{P}=0.004)$ and $20.542(\mathrm{P}<0.000)$. Overall, the patients appeared satisfied in all the five domains after consultation with homeopathic doctors. 
Table 4: The relationship between total score or subscales and VASs to assess the concurrent validity ( $\mathrm{n}=390)$

\begin{tabular}{|l|c|l|}
\hline Subscales & Correlation with VAS: Pearson's $r$ & $\mathrm{P}$ value; statistical significance \\
\hline Total score & 0.60306 & $\mathrm{P}<0.001$; extremely significant \\
\hline Overall satisfaction & 0.82941 & $\mathrm{P}<0.0001$; extremely significant \\
\hline Q1 & 0.86554 & $\mathrm{P}<0.0001$; extremely significant \\
Q2 & 0.93736 & $\mathrm{P}<0.0001$; extremely significant \\
\hline Complete examination & 0.90305 & $\mathrm{P}<0.0001$; extremely significant \\
\hline Q3 & 0.93204 & $\mathrm{P}<0.0001$; extremely significant \\
Q4 & 0.97224 & $\mathrm{P}<0.0001$; extremely significant \\
\hline Whole person care & 0.90492 & $\mathrm{P}<0.0001$; extremely significant \\
\hline Q5 & 0.96219 & $\mathrm{P}<0.0001$; extremely significant \\
Q6 & 0.95852 & $\mathrm{P}<0.0001$; extremely significant \\
\hline Examination time & 0.87662 & $\mathrm{P}<0.0001$; extremely significant \\
\hline Q7 & 0.96349 & $\mathrm{P}<0.0001$; extremely significant \\
Q8 & 0.96896 & $\mathrm{P}<0.0001 ;$ extremely significant \\
Q9 & 0.89544 & $\mathrm{P}<0.0001 ;$ extremely significant \\
\hline Patient centeredness & 0.89281 & $\mathrm{P}<0.0001 ;$ extremely significant \\
\hline Q10 & 0.93669 & $\mathrm{P}<0.0001$; extremely significant \\
Q11 & 0.96558 & $\mathrm{P}<0.0001$ extremely significant \\
Q12 & 0.90080 & $\mathrm{P}<0.0001$; extremely significant \\
\hline
\end{tabular}

$r$ : Pearson's product-moment correlation coefficient

Table 5: OPD distribution of obtained questionnaires and dimensions scores

\begin{tabular}{|l|c|c|c|c|c|}
\hline Dimensions & $\begin{array}{c}\text { Male } \\
\text { Medicine } \\
(\mathrm{n}=88)\end{array}$ & $\begin{array}{c}\text { Female } \\
\text { Medicine } \\
(\mathrm{n}=67)\end{array}$ & $\begin{array}{c}\text { Gynecology } \\
\text { and } \\
\text { Obstetrics } \\
(\mathrm{n}=80)\end{array}$ & $\begin{array}{c}\text { Surgery } \\
(\mathrm{n}=72)\end{array}$ & $\begin{array}{c}\text { Pediatrics } \\
(\mathrm{n}=83)\end{array}$ \\
\hline Overall satisfaction & $3.5 \pm 0.7$ & $3.5 \pm 0.5$ & $3.8 \pm 0.4$ & $3.6 \pm 0.6$ & $3.7 \pm 0.6$ \\
& $82 \pm 9$ & $84 \pm 14$ & $85 \pm 6$ & $83 \pm 12$ & $85 \pm 18$ \\
\hline Complete examination & $3.5 \pm 0.4$ & $3.3 \pm 0.7$ & $3.7 \pm 0.5$ & $3.5 \pm 0.8$ & $3.9 \pm 0.5$ \\
& $82 \pm 14$ & $80 \pm 18$ & $83 \pm 6$ & $81 \pm 14$ & $90 \pm 11$ \\
\hline Whole person care & $3.5 \pm 0.6$ & $3.3 \pm 0.8$ & $3.7 \pm 0.5$ & $3.3 \pm 0.7$ & $3.8 \pm 0.4$ \\
& $87 \pm 14$ & $80 \pm 17$ & $83 \pm 7$ & $77 \pm 13$ & $89 \pm 12$ \\
\hline Examination time & $3.7 \pm 0.7$ & $3.3 \pm 0.7$ & $3.4 \pm 0.8$ & $3 \pm 1$ & $3.7 \pm 0.7$ \\
& $82 \pm 17$ & $81 \pm 16$ & $75 \pm 20$ & $76 \pm 17$ & $85 \pm 20$ \\
\hline Patient centeredness & $3.5 \pm 0.6$ & $3.4 \pm 0.6$ & $3.5 \pm 0.5$ & $3.2 \pm 0.7$ & $3.8 \pm 0.5$ \\
& $87 \pm 9$ & $82 \pm 13$ & $82 \pm 6$ & $75 \pm 11$ & $89 \pm 13$ \\
\hline
\end{tabular}

n: number of patients; SD: Standard Deviation; VAS: Visual Analogue Scale; CI: Confidence interval 
Kappa statistics - Table 6 shows that Cohen's kappa values for each question item were greater than 0.7, and that the test and re-test scores were highly correlated. It also shows that the questionnaire is reliable and reproducible.

Table 6: Kappa scores for each question to assess the test-retest reliability $(n=45)$

\begin{tabular}{|l|c|}
\hline Question items & Cohen's Kappa (к) score \\
\hline Overall satisfaction & 0.903 \\
\hline Q1 & 0.857 \\
Q2 & 0.819 \\
\hline Complete examination & 0.726 \\
\hline Q3 & 0.825 \\
Q4 & 0.823 \\
\hline Whole person care & 0.764 \\
\hline Q5 & 0.751 \\
Q6 & 0.844 \\
\hline Examination time & 0.812 \\
\hline Q7 & 0.855 \\
Q8 & 0.872 \\
Q9 & 0.895 \\
\hline Patient centeredness & 0.768 \\
\hline Q10 & 0.741 \\
Q11 & 0.774 \\
Q12 & 0.714 \\
\hline
\end{tabular}

\section{Discussion}

A wide variety of methods are being used ranging from the use of commercial survey systems and nationally validated measures to locally devised patient questionnaires and qualitative methods [5]. However, most consultation satisfaction questionnaires relate to doctor-patient contacts [5].

In this study, the Japanese short form self-administered consultation satisfaction questionnaire retained its validity and reliability including concurrent and discriminant validity, internal consistency and test-retest reliability when used to assess patient satisfaction in a Government homeopathic hospital in West Bengal, India. Patient satisfaction was computed to be quite satisfactory to high. The questionnaire appears to be a useful measure of patient satisfaction, easy to administer, and applicable in Bengali speaking people in West Bengal. To the best of our knowledge, these questionnaires have never been investigated till date in any homeopathic hospital setting. The large number of subjects involved increases the power of the analyses [8]. Fewer items of this questionnaire enhanced the patient response and diminished patient burden [8].

However, the findings may or may not hold for other general homeopathic practice settings; these should be treated cautiously as they do not take into account other variables such as the nature of the conditions treated [5], or the culture and ethnicity of patients. The questionnaire attempts to measure satisfaction with a particular individual encounter as distinct from general attitudes towards physicians or health care service. 
Because items in the questionnaire refer directly to a specific patient-physician interaction, it is likely to be more sensitive to actual differences in care of the encounter [8]. The number of subjects used to examine the test-retest reliability may seem to be insufficient; however it is comparable to that of other similar studies and may be considered satisfactory [8]. Though the validity and reliability of the questionnaire were re-evaluated in this study and were found to be acceptable, it is still difficult to assess a subjective feeling of satisfaction through questionnaire [8]. Another limitation is that this questionnaire is difficult to implement in patients not speaking Bengali.

The present result may be considered as only preliminary and further works should be undertaken adapting the questionnaire globally in multicentric design. This type of study may be beneficial in improving the clinical interview skills of homeopathic doctors, trainees and students of the institution [8]. The cumulative effect can potentially lead to greater patient satisfaction and ultimately improved health care.

\section{Acknowledgement}

Dr. Rajkumar Manchanda (Director General, CCRH, New Delhi, Govt. of India) and Dr. Amitava Biswas (Principal, MBHMC\&H, Govt. of West Bengal, India) for technical assistance, constant guidance, encouragement, and permission to conduct the study.

\section{References}

[1] Hall JA, Feldstein M, Fretwell MD, Rowe JW, Epstein AM. Older patients' health status and satisfaction with medical care in an HMO population. Med Care 1990;28:261-70.

[2] Bradley C, Lewis K. Measures of psychological well-being and treatment satisfaction developed from responses of people with tablet treated diabetes. Diabetic Med 1990;7:445-51.

[3] Fitzpatrick R, Bury M, Frank A, Donnelly T. Problems in the assessment of outcome in a back pain clinic. IntDisabil Stud 1987;9:165.

[4] Meakin R, Weinman J. The 'Medical Interview Satisfaction Scale' (MISS-21) adapted for British general practice. Family Practice 2002;19(3); @Oxford University Press, 2002.

[5] Poulton BC. Use of the consultation satisfaction questionnaire to examine patients' satisfaction with general practitioners and community nurses: reliability, replicability and discriminant validity. Br J Gen Pract 1996;46:26-31.

[6] Roghmann K, Hengst A, Zastowny T. Satisfaction with medical care: its measurement and relation to utilization. Med Care 1979;17:461-77.

[7] Orton M, Fitzpatrick R, Fuller A, Mant D, Mlyneck C, Thorogood M. factors affecting women's response to an invitation to attend for a second breast cancer screening examination. Br J Gen Pract 1991;41:320-3.

[8] Takemura Y, Liu J, Atsumi R, Tsuda T. Development of a questionnaire to evaluate patient satisfaction with medical encounters. Tohoku J Exp Med 2006;210:373-81.

[9] Wolf MH, Putnam SM, James AJ, Stiles WB. The medical interview satisfaction scale: development of a scale to measure patient perceptions of physician behavior. J Behav Med 1978;1:391-401.

[10] Wolf MH, Stiles WB. Further development of the medical interview satisfaction scale. Paper presented at the American Psychological Association Convention, Los Angeles (CA), 1981. 
[11] Berhane A, Getahun A, Azanaw A, Hamza S. What patients want to know about their medication? A survey of inpatients and outpatients at Gondar University Hospital.Int J Pharm Sci Res, Jan 2013; 4(1): 4349.

[12] World Health Organization. The Alma-Ata conference on primary health care. WHO Chronicle, 1978; 32 : 409-30.

[13] C2013, NumberEmpire; accessed on 2013 March 14. Available at: http://www.numberempire.com/statisticscalculator.php;

[14] (O2013, endmemo.com; accessed on 2013 March 14. Available at: http://www.endmemo.com/statistics/kurtosis.php;

[15] C2004-2013, Measuring Usability LLC; accessed on 2013 March 13. Available at: http://www.usablestat.com/lesson5/sdExcel;

[16] OJumk.de WebProjects; accessed on 2013 March 13. Available at: http://www.jumk.de/statisticcalculator/;

[17] Wessa P, 2012. Cronbach's alpha (v 1.0.2) in Free Statistics Software (v 1.1.23 - r7), Office for Research Development and Education; available at: http://www.wessa.net/rwasp_cronbach.wasp/; OWessa.Net 20022013; accessed on 2013 March 13.

[18] Wessa P, 2012. Pearson Correlation (v 1.0.6) in Free Statistics Software (v 1.1.23 - r7), Office for Research Development and Education; available from: http://www.wessa.net/rwasp-correlation.wasp \#output; CWessa.Net 2002-2013; accessed on 2013 March 13.

[19] @2011, DeenFreelon; accessed on 2013 March 15. Available at: http://dfreelon.org/recal/recal2.php\#result/; Available at: http://www.danilsoper.com/statcalc3/calc.aspx?id=43; Statistics Calculators v3.0 Beta; (C2006-2013, Dr. Daniel Soper; accessed on 2013 March 15.

\section{Avaliação da satisfação dos pacientes em um hospital homeopático público, em Bengala Ocidental, Índia}

\section{RESUMO}

Introdução e objetivos: A determinação do grau de satisfação dos pacientes de um hospital homeopático, pode producir impacto substancial nos esforços para melhorar o o estado de saúde e a qualidade da atenção proporcionada. Neste estudo, avaliamos o grau de satisfação dos pacientes, depois das consultas médicas, bem como a validade e confiabilidade do questionário utilizado. Métodos: Estudo transversal com desenho observacional realizado em fevereiro de 2013 com 390 voluntários em 5 ambulatórios da Facultade e Hospital de Medicina Homeopática Mahesh Bhattacharyya, pertencente a rede pública Bengala Ocidental, Howrah, India. Foi autoaplicado um breve questionário japonês de satisfação com as consultas médicas, traduzido para o bengalí, com 12 ítems respondidos em uma escala tipo Likert de 5 pontos. O questionario gerou 5 sub-escalas: satisfação global; exame completo; atenção do paciente como um todo; duração da consulta; foco no paciente. As respostas de cada ítem e sub-escala também incluíam uma escala visual analógica de $100 \mathrm{~mm}$. Resultados: O questionário se mostrou válido e confiável. Sua consistência interna foi comprovada por valores entre 0,7 e 0,9 do coeficiente $\alpha$ de Cronbach, e a confiabilidade teste-reteste pelo coeficiente kappa de Cohen, cujo valor foi superior a $0,7 \mathrm{em}$ todos os ítens. A validez concorrente do coeficiente $\mathrm{r}$ de Pearson correspondente a pontuação total do 
questionário a as EVAs foram de 0,60, p<0,001; pontuação de cada escala $0,8<r<0,9$, p < 0,0001 , e pontuação de cada ítem $0,8<r<0,9, \mathrm{p}<0,0001$. A comparação das pontuações médias das 5 subescalas correspondentes aos 5 ambulatorios resultaram en valores de razão $F$ de 4,3-9,8 (p<0,05, $\mathrm{df}=4$, intervalo de confiança de $95 \%$ ), comprovando a validez discriminante do questionário. Em geral, os pacientes reportaram alta satisfação. Novos estudos são necessários para adaptar o questionário utilizado neste estudo a outros idiomas, para uso global.

Palabras chave: consulta médica, homeopatía, satisfação do paciente, questionários.

\title{
Evaluación de la satisfacción de pacientes en un hospital homeopático público en Bengala Occidental, India
}

\begin{abstract}
RESUMEN
Introducción y objetivos: La determinación del grado de satisfacción de los pacientes de un hospital homeopático puede producir impacto sustancial en los esfuerzos para mejorar el estado de salud y la calidad de la atención proporcionada. En este estudio, los investigadores evaluaron el grado de satisfacción de los pacientes después de consultas médicas, al igual que la validez y confiabilidad del cuestionario utilizado. Métodos: Estudio transversal con diseño observacional realizado en febrero de 2013 con 390 voluntarios en 5 ambulatorios de la Facultad y Hospital de Medicina Homeopática Mahesh Bhattacharyya, perteneciente a la red pública de Bengala Occidental, Howrah, India. Fue auto-aplicado un breve cuestionario japonés de satisfacción con consultas médicas traducido al bengalí, con 12 ítems respondidos en una escala tipo Likert de 5 puntos. El cuestionario generó 5 sub-escalas: satisfacción global; examen completo; atención del paciente como un todo; duración de la consulta; foco en el paciente. Las respuestas de cada ítem y sub-escala también incluían una escala visual analógica de $100 \mathrm{~mm}$. Resultados: El cuestionario se mostró válido y confiable. Su consistencia interna fue comprobada por valores entre 0,7 y 0,9 del coeficiente $\alpha$ de Cronbach, y la confiabilidad test-retest por el coeficiente kappa de Cohen, cuyo valor fue superior a 0,7 en todos los ítems. La validez concurrente del coeficiente $r$ de Pearson correspondiente al puntaje total del cuestionario y las EVAs fue de 0,60, p<0,001; puntaje de cada escala $0,8<r<0,9, \mathrm{p}<0,0001$, y puntaje de cada ítem $0,8<r<0,9$, p $<0,0001$. La comparación de los puntajes promedio de las 5 sub-escalas correspondientes a los 5 ambulatorios resultó en valores de razón $F$ de 4,3-9,8 (p<0,05, df = 4, intervalo de confianza al 95\%), comprobando la validez discriminante del cuestionario. En general, los pacientes reportaron alta satisfacción. Nuevos estudios son necesarios para adaptar el cuestionario utilizado en este estudio a otros idiomas para uso global.
\end{abstract}

Palabras clave: consulta médica, homeopatía, satisfacción del paciente, cuestionarios.

\section{(c)) BY-NC-ND Licensed to GIRI}

Support: authors declare that this study received no funding

Conflict of interest: authors declare there is no conflict of interest

Received: March18 ${ }^{\text {th }}, 2013$; Revised:June 18 ${ }^{\text {th }}, 2013$; Published: June 30 $30^{\text {th }}, 2013$.

Correspondence author: Munmun Koley, dr.mkoley@gmail.com

How to cite this article:Koley M, Saha S, Ghosh S,Mukherjee R, Kundu B, Mondal R, Purkait R,Arya JS, Choubey G. Evaluation of patient satisfaction in a Government Homeopathic Hospital in West Bengal, India. Int J High Dilution Res [online]. 2013[cited YYYY Month dd]; $12(43)$ : 52-61. Available from: http://www.feg.unesp.br/ ojs/index.php/ijhdr/article/view/629/634 